AUTHOR: Ihsan Yılmaz \& Kainat Shakil

\title{
Imran Khan: From Gricket Batsman to Populist Captain Tabdeli of Pakistan
}

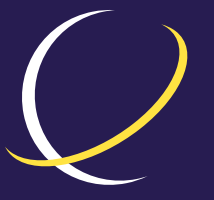




\section{Imran Khan: From Cricket Batsman to Populist Captain Tabdeli of Pakistan}

BY IHSAN YILMAZ \& KAINAT SHAKIL

\section{ABSTRACT}

Imran Khan is not the first to use populism to wield power in Pakistan. Religious leaders, political figures, and military generals have used faith and the promise of a better life to gain support or legitimize their actions. The uniqueness of Khan's populism lies in the fact that he has been able to condense a host of diverse ideologies into a coherent populist narrative that has endeared him to "the people."

IHSAN YILMAZ is Research Professor and Chair of Islamic Studies and Intercultural Dialogue at the Alfred Deakin Institute for Citizenship and Globalisation (ADI), Deakin University, Melbourne, Australia.

KAINAT SHAKIL is a research fellow at The Shahid Javed Burki Institute of Public Policy at NetSol (BIPP) - a Pakistan based think-tank - where her work has focused on reviewing public policies from a people centric perspective for better public representation, ownership, and participation. A large part of her work is qualitative research mapping to understand the perceptions, feelings, reactions, and engagement of the public with government policies and vice versa.

ECPS Leader Profile Series offer analyses of political leaders and prominent public figures with populist tendencies. Unless otherwise indicated, the views expressed by the author are only attributable him and not to any institution with which they are associated.

The profile available for free downloading from the ECPS website (www. populismstudies.org)

(C)ECPS 2021 


\section{Table of contents}

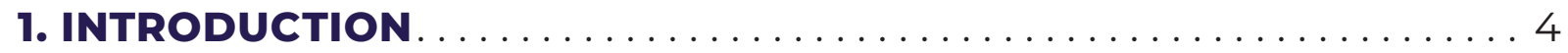

2. THE ICONIC SPORTSPERSON $\ldots \ldots \ldots \ldots \ldots \ldots \ldots \ldots \ldots \ldots \ldots$

3. THE BEGINNING Of A POLITICAL CAREER $\ldots \ldots \ldots \ldots \ldots \ldots \ldots$

4. REMODELLING THE KAPTAN $\ldots \ldots \ldots \ldots \ldots \ldots \ldots$

5. FROM PAKISTAN'S LAST HOPE TO “U-TURN” KHAN . ........... 11

6. MAINSTREAM OPPOSITION $(2013-2018) \ldots \ldots \ldots \ldots \ldots \ldots \ldots \ldots \ldots$

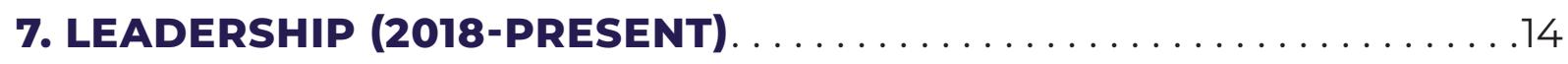

8. KHAN'S POPULISM AND ITS CONSEQUENCES $\ldots \ldots \ldots \ldots \ldots \ldots$

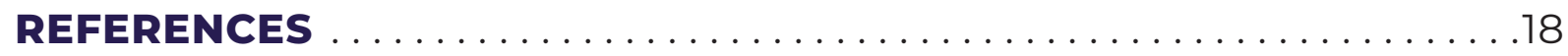

FOOTNOTES ...................................... 22 


\section{INTRODUCTION}

Imran Khan's journey to the corridors of parliament is unique for a country like Pakistan. Most political personalities in Pakistan have risen from the landed elites (the jagirdars), a small group of business tycoons, or the military - the latter, dictators turned "democrats."

Pakistan's first democratic, pseudo-populist leader, the iconic Zulfiqar Ali Bhutto, was a member of the landed elite in Sindh; his grandfather and father were both active in the politics of British India. Following Bhutto's execution, leaders from his party, Pakistan People's Party (PPP), were family members, including his daughter Benazir Bhutto, his son-in-law Asif Ali Zardari, and currently, his grandson, Bilawal Bhutto-Zardari.

The other major leadership during the country's intermittent democratic periods have emerged from the Sharif family. With a background in the steel industry, the brothers Shahbaz and Nawaz Sharif rose to power in the 1980s, promoted by the dictator Zia ul Haqas as a right-wing counter to the left-leaning PPP. The Sharifs rose to power from the heartland of Punjab; today, the second generation of Sharifs is guided by Mariam Nawaz and Hamza Shahbaz, the faces of the Pakistan Muslim League Nawaz (PML-N).

Amidst this backdrop, smaller parties have also horse-traded, generally relying on fraternity, kinships, wealth, and religion to amass support.

Imran Khan's immediate family did not come from an elite business or agrarian background. Rather, he was raised in an upper-middle-class family with an engineer father and a homemaker mother. He did not pursue politics as a career until his late 40s; before politics, played international cricket. To understand Khan's political personality, one must thoroughly understand his public image before his political career began. 


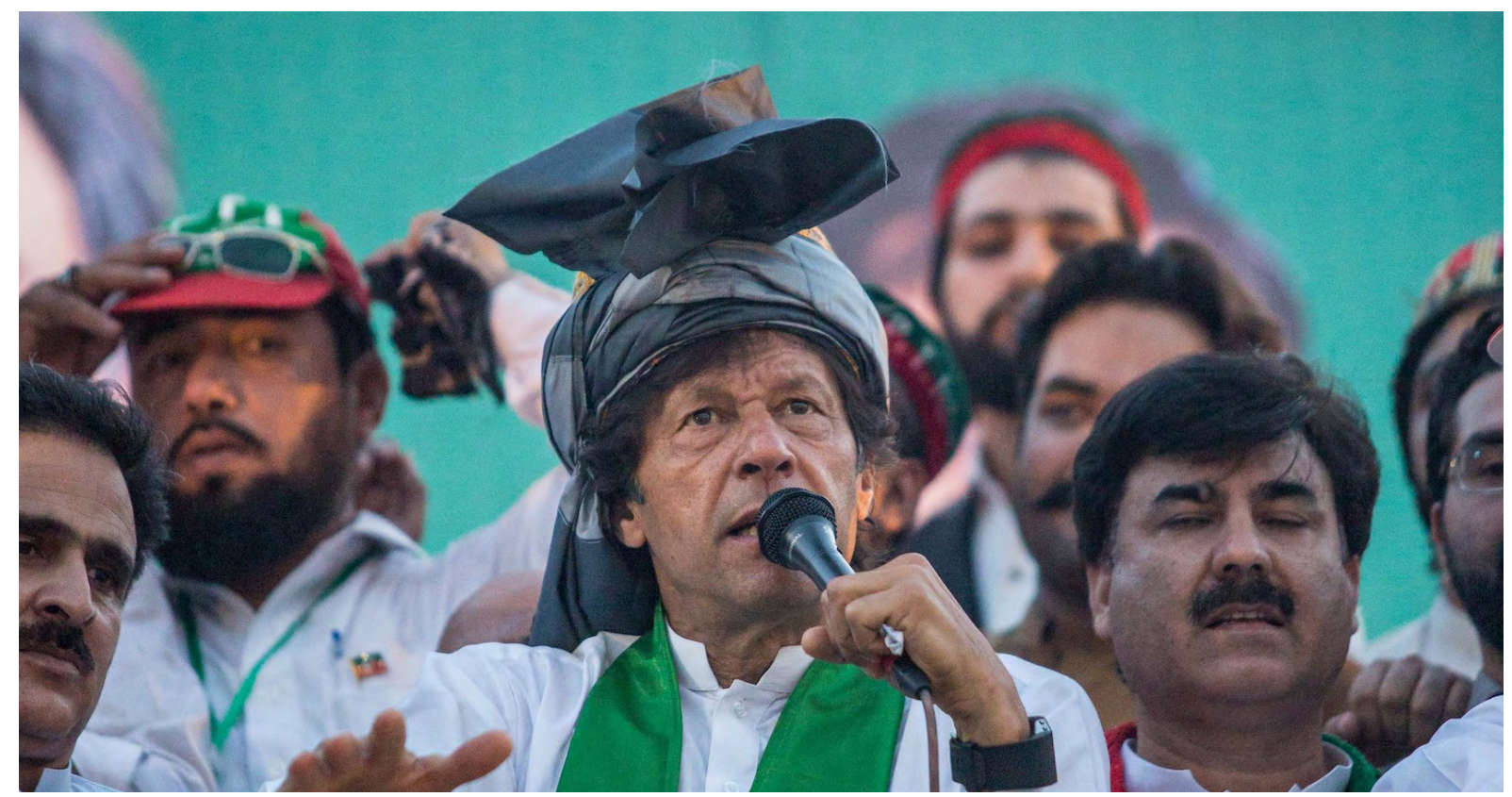

Tehreek-e-Insaf (PTI) Chairman, Imran Khan addresses to public meeting held at Shahi Bagh in Peshawar on May 27, 2015. Photo: Awais Khan

\section{The Iconic Sportsperson}

It is notable that many populist leaders portray themselves as a political "outsider," thus promising a fresh start. Khan is also considered an outsider. An iconic cricketer, Khan dominated the cricketing world in the 1980s and 1990s. He was an Oxford-educated, anglicized Pakistani sportsman who spent most of his time overseas. Even before he became a national hero in 1992, Khan was a wellliked figure in Pakistan, due to his boyish charm and sportsmanship.

He became a hero while captain of Pakistan's national cricket team. Under his captaincy, Pakistan won its first and only Cricket World Cup in 1992 after a hotly contested match against England. Cricket is one of the most watched and followed sports in Pakistan and holds a deep national significance. To millions of Pakistanis, Khan was the leader who led the nation to the much-awaited victory. The victory is cemented in the collective memory of Pakistanis as a miracle made possibly by Khan's leadership. The Prime Minster and his party members have repeatedly used the victory to reaffirm the people's faith in the "Captain's" capabilities.

To gain legitimacy as a political leader, Khan extensively changed his personal outlook, from that of a Westernized cricketer to an Islamized philanthropic politician. In 1988, Khan published an autobiographical account of his life in Imran Khan: An All-Rounder View. Revised in 1993, this was an account of his cricketing career. He also discussed coming to terms with his Muslim heritage and identity after spending considerable time in Western institutions. Khan put out another title in 1989, Imran Khan's Cricket Skills. This book was meant for fans of the sport, to be used as a guide for honing their cricket skills. Using his celebrity status, Khan published a travelogue, Indus Journey: A Personal View of Pakistan in 1990. After admitting that he had come to terms with his identity, in his travelogue, Khan crossed the country and relived his memories of visiting key settlements and remains along the Indus River, showcasing Pakistan's rich cultural heritage ${ }^{[2]}$.

Three years later, in 1993, Khan published Warrior Race: A Journey Through the Land of the Tribal Pathans. The books dug even deeper into his heritage. The progression of his books shows that during the last years of his cricket career, he increasingly identified with his Pakistani and Muslim identity, shunning his westernized influ- 
ences. His increasing interest and concern for Pakistan was visible in the considerable amount of time he began spending on philanthropy. Khan established the first cancer hospital in Pakistan, Shaukat Khanum Memorial Cancer Hospital and Research Centre, in 1994. There was a personal side to this act, as Khan's mother had succumbed to cancer which inspired him build the hospital.

The hospital now has branches in Lahore, Peshawar, and Karachi (under construction). They provide world class free healthcare to oncology patients who could otherwise not afford treatment. Khan's charitable work also led him to establish a not-for-profit educational institute, Namal.

He accomplished these mega projects with tremendous support and faith from the public. He ran unparalleled cross-cultural campaigns to raise funds. The fundraisers were high-profile events; Princess Diana of Wales even attended one, while at the grassroots level, children called "Tigers" collected funds for the cause.

The "reformed" image of an anglicized schoolboy become Pakistan's hero philanthropist helped start Khan's political

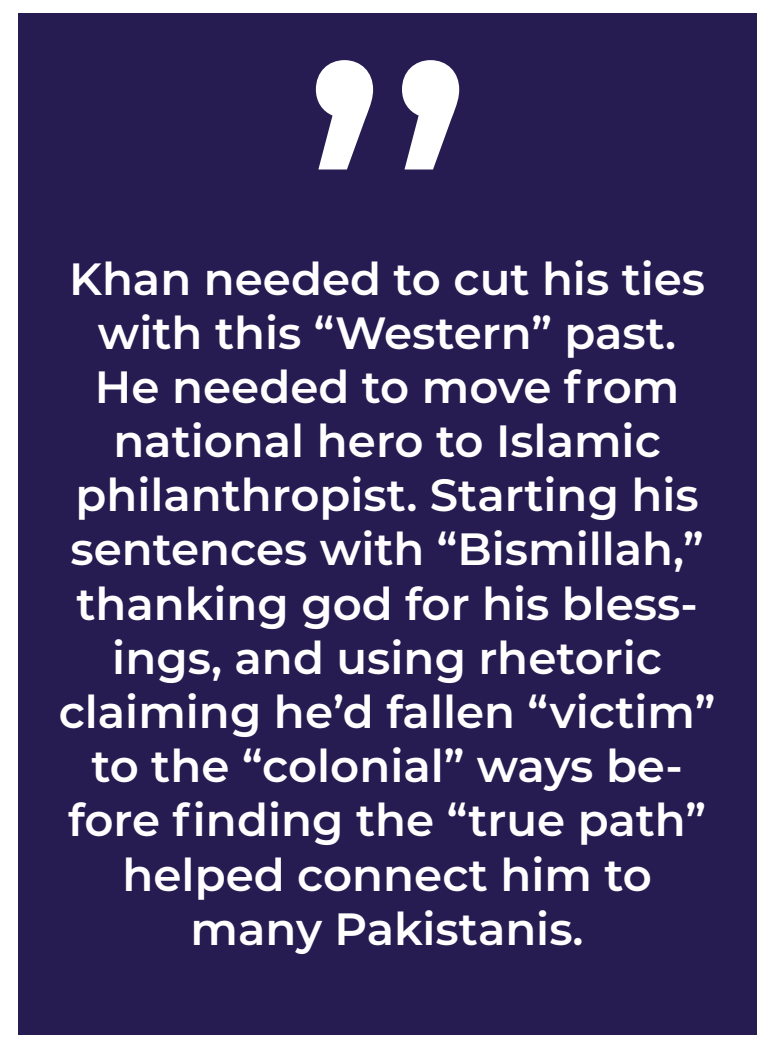

career: Khan launched his political party, the Pakistan Tehreek-e-Insaf (PTI), ${ }^{[3]}$ in 1996. PTI was a small, personality-driven party, run by Khan and several of his close friends and family members. The party catered to the population with a promise of reformist ideals - to deliver "justice" to "the people."

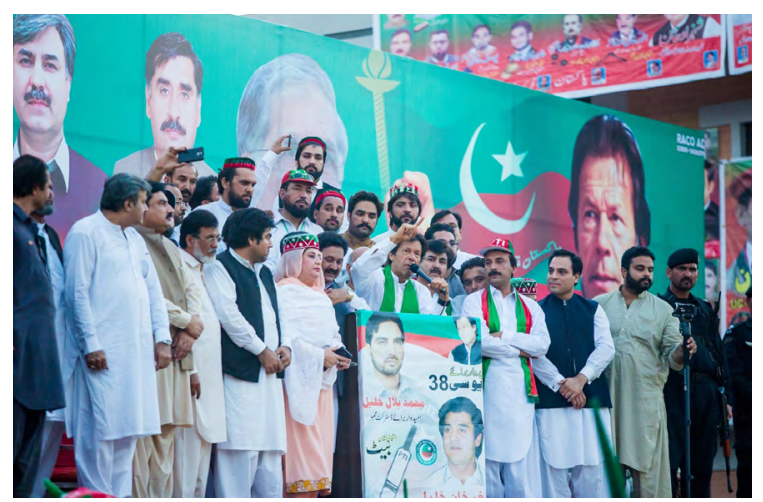

Tehreek-e-Insaf (PTI) Chairman, Imran Khan addresses to public meeting held at Shahi Bagh in Peshawar, Pakistan on May 27, 2015. Photo: Awais Khan

\section{The Beginning of a Political Career}

In his most recent publication, Pakistan: A Personal History, published in 2011, Khan largely focused on his struggles with the PTI. He repeatedly and aggressively asserts his "Muslimness" in this book, a shift that coincides with his changing political ideology. Khan aligned himself with the populist religious sentiments of the conservative populace, a necessity for gaining political support.

Khan was married to Jemima Goldsmith from 1995 to 2004. Goldsmith comes from a well-known Jewish family from Britain; this was a huge problem for Khan's public image in Pakistan, where anti-Semitism and Zionist conspiracy theories are common (Aafreedi, 2019). It was unclear during the period if Goldsmith accepted Islam or not, another scandalous issue for Khan. He was also frequently photographed at niche, elite parties, where alcohol was the norm. ${ }^{[4]}$ There were alleged affairs with models and socialites, further tarnishing his image. To make matters worse, Sita White, an American heiress, claimed Khan 
was the father of her daughter born out of wedlock (a claim disputed by Khan) ${ }^{[5]}$ (Irish Times, 1997).

Khan needed to cut his ties with this "Western" past. He needed to move from national hero to Islamic philanthropist. Starting his sentences with "Bismillah," thanking god for his blessings, and using rhetoric claiming he'd fallen "victim" to the "colonial" ways before finding the "true path" helped connect him to many Pakistanis, who feel defying the "Western" way of life is a test of one's Muslimness.

Khan was offered positions in the government of dictator General Zia ul Haq in 1988 and later in a caretaker government in 1993; he declined both (Mir, 2018). His decision to stay as an "outsider" further bolstered his claims as a political leader not chasing money or power but seeking to fight for the people.

Amidst this backdrop, Khan and the PTI competed in their first general elections in 1997. Their symbol was the cricket bat, despite Khan focusing more on his humanitarian work inspired by key Muslim figures such as Prophet Muhammad and his companions. Though the party lost handily, Khan stayed in the public eye. He was critical of the PML-N government and the military status quo under Pervez Musharraf. Khan's message was simple: "end corruption, clear out the political mafias" (The Guardian, 2008). He again declined invitations and pressure to join the pro-Musharraf alliance led by the Paki-

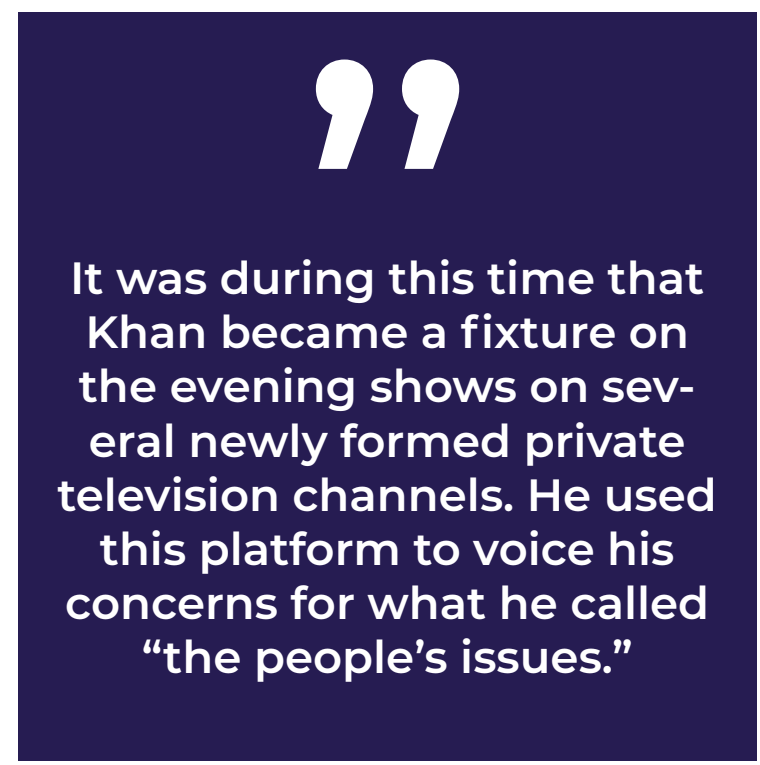

stan Muslim League-Nawaz (PML-Q), once more maintaining his status as an outsider (Mir, 2018).

The PTI won their first seat in the National Assembly in 2002. Post-9/11, Pakistan was engulfed in the war on terror. Pakistan's proximity to Afghanistan made it a close ally of the US and the Bush administration. On Pakistan's western front, a porous border, wild terrain, a lack of governance, and the presence of local radical factions allowed for fleeing Taliban members to seek shelter. Over the next decade, Pakistan was seriously impacted by the war in Afghanistan. Public and military buildings - including markets, shrines, and schools - were targeted by suicide bombers; radicalism surged, and so did the military's involvement in various operations in an attempt to drive out the radicals. The US used drones to target various radical and Taliban leaders, killing large numbers of civilians and destroying property. The region saw an influx of refugees from Afghanistan and scores of internally displaced people, too.

It was during this time that Khan became a fixture on the evening shows on several newly formed private television channels. He used this platform to voice his concerns for what he called "the people's issues." He railed against the government for not aiding internally displaced citizens and for becoming so dependent on the US, it wouldn't object to the drone strikes on sovereign Pakistani soil. Educated, middle-class Pakistanis responded to his humanitarian narrative: "Are these people not humans? These humans have names. Drone attacks are a violation of human rights" (Chowdhry \& Houreld, 2012).

Khan took an openly critical view of the situation, and one of his interviews sums up his stance: "We (Pakistan and the CIA and USA), created these militant groups to fight the Soviets... Jihadis were heroes then....... the US packs up and leaves Afghanistan... And we were left with these groups.... Pakistan again joins the US (post $9 / 11$ ) in the war on terror and now we are required to go after these groups as terrorists... so, Pakistan took a real battering in this" (Press Trust of India, 2019). 
Opposition to government and US involvement continued throughout this period. These views were in line with public sentiment, as most conservatives opposed the US and civil society felt cornered under the autocratic, military-led government. Another humanitarian issue, popular in war torn areas and amongst civil society groups, concerned missing persons ${ }^{[6]}$. Khan also took up the mantle for this cause, specifically missing persons from Balochistan. Once more, the government was seen as negligent and too beholden to the US (Mir, 2018).

Khan was the politician who brought these issues to light while the PPP and PML-N stayed silent on matters regarding, for instance, the right to a free trial and other civil liberties and safeties. Khan was "brave" and "outspoken," a man who spoke for "justice" by standing up to the US. After winning his first seat in the National Assembly, Khan continued his crusade against US influence and "puppet politicians" as he spent most of his time in office acting as a lone opposition voice on terrorism-related issues and civilian rights. By the end of the Musharraf regime, Khan had staged several protests - such as hunger strikes - for the restoration of unconstitutionally dismissed judges and actively took part in an alliance along with other major parties and civil society members to call for new and fair elections in 2008 (Inskeep, 2008; Walsh 2007).

Khan's increasing anti-West rhetoric also coincided with his divorce from Goldsmith in 2004. The former cricketer, who once frequently wore Western clothes, now appeared increasingly in the Pakistani-styled kurta and shalwar and was no longer married to a "Jewish foreigner." He increasingly raised "Muslim" issues and characterized the American war in Afghanistan and its impacts on Pakistan as a "West versus Islam" issue, a highly popular narrative with the general public. He became the face of the protests surrounding issue of desecrating the Quran at Guantanamo Bay in 2005. Khan exclaimed, "This is what the US is doing... desecrating the Quran" (Rajghatta, 2005). His comments greatly undermined Musharraf, causing mass civil unrest in Pakistan and Afghanistan, which led to 16 people killed in rioting in Afghanistan (The Week, 2020). As part of his opposition to Pakistan's involvement in the war on terror, he also led protests to blockade food and army supplies from the North Atlantic Treaty Organization (NATO) at the Peshawar highway, en route to Afghanistan (Express Tribune, 2011). All of this was viewed as "heroic" in the eyes of many Pakistanis who did not approve of their country's involvement in the American's Afghan war.

Khan refused to partake in the 2008 elections, which he felt were not free and fair. Questioning the electoral credibility of the country's democratic system added a new dimension to his populism. Before the elections he said, "Across the spectrum, from the right to the left, [Pakistanis] want Musharraf to go.... The U.S. administration must be getting this information. In Pakistan, according to all the polls, [U.S. officials] are backing someone who is deeply unpopular in the country" (Inskeep, 2008). He expressed deep resentment towards the regime. Soon, Musharraf resigned, and a PPP-led government came to power while Khan remained outside politics until his party participated again in the 2013 elections, where they had their most successful campaign ever, winning a majority of seats in Khyber Pakhtunkhwa (KPK) province. 


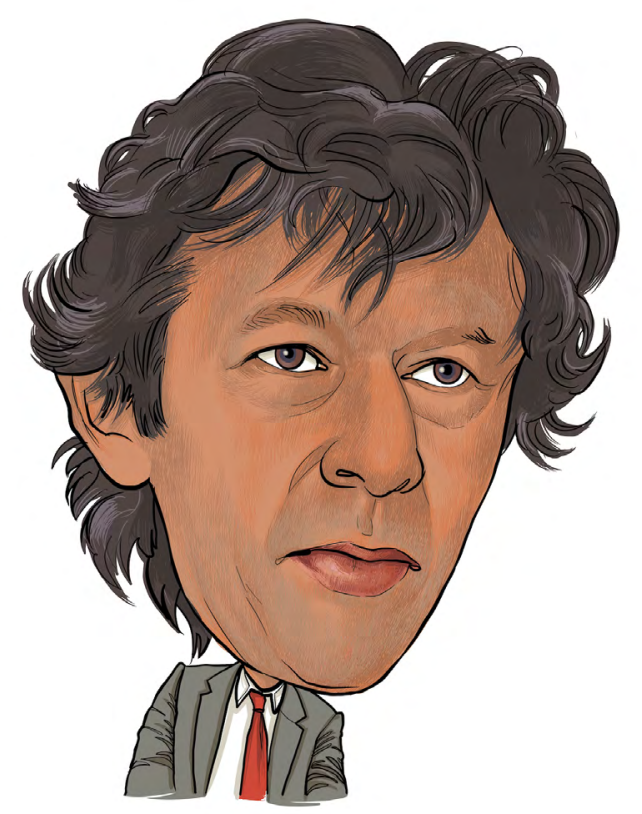

\section{Remodelling the} Kaptan ${ }^{[7]}$

Khan rapidly rebranded from 2008-2013. His new, populist, Islamized brand was spread on private media channels and on social media platforms such as Facebook.

He increasingly asserted that his decision to enter politics was for "the people" and not for fame, money, or power - in contrast to the "corrupt elite" politicians who were in power. Khan also asserted he felt the "pain" of the masses and sought inspiration from the work of pan-Islamist philosophers and freedom movement political leaders, to finally realize the Pakistan that Muhammad Ali Jinnah had envisioned. Since his autobiography's publication in 2011, Khan used the examples of Prophet Mohammed and the first four Muslim Caliphs to highlight his aspirations to deliver good governance on the "Islamic model."

By the early 2010s, Imran Khan had shunned his western ways and aligned with populist issues concerning religion and governance. He said, "I call them ['Westernized' Pakistanis] coconuts: brown on the outside, white on the inside, looking at Pakistan through a westernised lens" (Walsh, 2011). Before the 2013 elections, he leaned into anti-American rhet- oric, anti-corruption slogans, and quick fixes to the people's problems - and he spread this message at huge rallies called jalsas, hosted across the country.

While Khan had become more "Muslim," his outlook and rhetoric balanced this newfound religiosity with a host of liberal ideologies. On most issues, he remained vague - the biggest example of this being his conviction about the "good" and "bad"

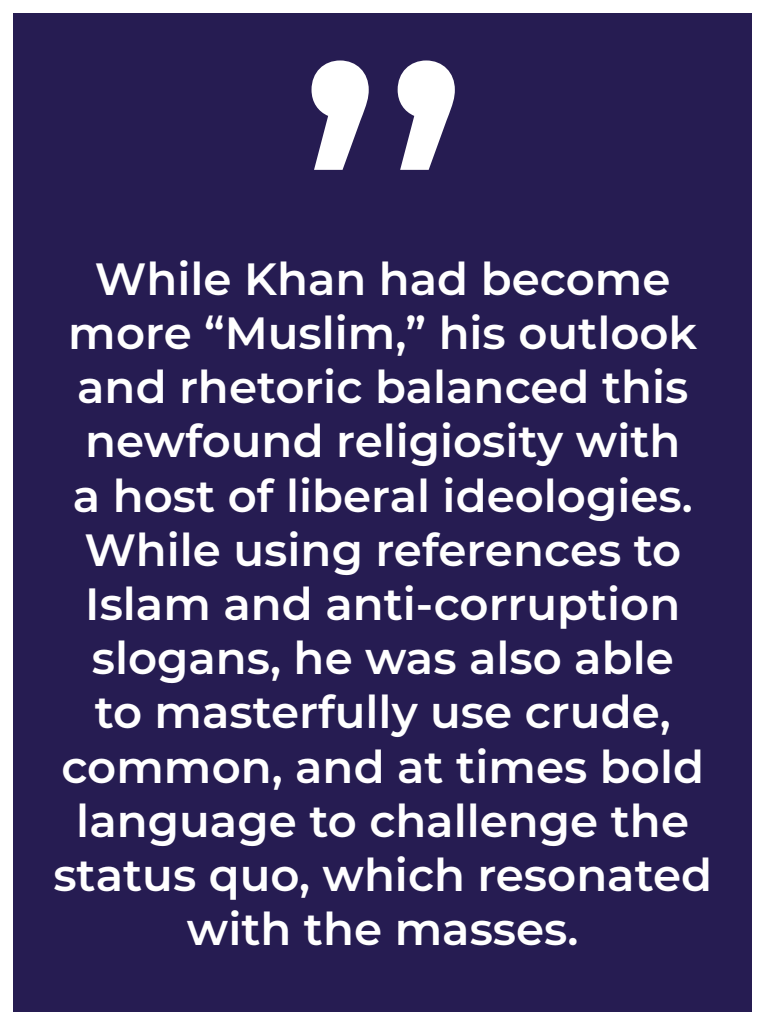


Taliban. Khan has repeatedly asserted that the Taliban were created by the US as a counter to the Soviet forces in Afghanistan in the 1980s; abandoned by the US, these groups - originally called the Mujahideen - turned against their former allies, resulting in the 9/11 attacks (Afzal, 2019; Mullah, 2017). Khan sought a peaceful resolution to the conflict and blamed the Pakistani and American governments for using controversial measures. To liberal factions, his call for meditation and rehabilitation was appealing, as military intervention had only made matters worse. At the same time, anti-West rhetoric was popular in conservative groups and his sympathy for the group, which Khan believed was justified by Islam, earned him the trust of extremist factions which previously saw him as part of Zionist conspiracy theories (Boone, 2012).

Khan saw cosmic justice or karma in the Taliban's "freedom fight" against the "outsiders"; with full confidence, Khan asserted, "It is very clear that whoever is fighting for their freedom is fighting a jihad ...The people who are fighting in Afghanistan against the foreign occupation are fighting a jihad" (Boone, 2012; Dawn; 2012). Khan supported the ultra-rightwing coalition Muttahida Majlis-e-Amal (MMA) and opposed operations against radical militants in the tribal areas. He also protested madrassa reforms. Together, these stances earned him the moniker, "Taliban Khan" in international media and favourable reception at home in both conservative and liberal circles (Pataudi, 2012; Guardian, 2005).

Corruption and governance were frequent features in Khan's vocabulary. The PPP's leader, Asif Ali Zardari, was known for rampant corruption during his wife's last two tenures as prime minister. This supported Khan when he called out the "corrupt elite." The PTI leader soon attacked PML-N leaders, such as Nawaz Sharif and Shahbaz Sharif, questioning their development programs in Punjab and in particularly Lahore, the province's capital and the hometown stronghold of the Sharifs. These programs were accused of focusing on infrastructure and beautification, ignoring the rampant poverty. Khan cast himself as an outsider and promised to fix the "people's" problems.
He wouldn't fill his pockets with "blood money." Khan's views can be summed up in an interview:

"I have been critical of the generals in the past. I told them they are selling our blood for dollars...But this is not martial rule. ${ }^{[8]}$ It's up to our corrupt government to take responsibility... We [him and the PTI] would go back to the people"(Walsh, 2011).

Media and social media brought Khan unapparelled fame, as his populist rhetoric was well received by the masses who yearned for change and relief. PTI jalsas were a unique occurrence and designed to create an intimate connection between "the leader" and "the people." PTI might have been the political party with many faces, but Imran Khan was the face of these gatherings.

Paradoxically, Khan's image successfully attracted members of the middle class to his gatherings. These events were like much loved melas ${ }^{[9]}$. Unlike other political rallies, they featured dancing - with women free to partake - and musical performance by leading Pakistani bands and singers. Particularly attracting urban younger and more "modern" citizens, ${ }^{[10]}$ these rallies - headlined by fiery speeches by Khan - were a mainstay of social media; tabdeli was a trending hashtag. The huge fan following that Imran Khan amassed led his followers to be called youthias (youngsters), or more commonly insafyans (justice seeks). By the early 2010s, Khan's populism was an amalgamation of piecemeal ideologies rooted in Islamism, anti-Westernism, anti-elitism, calls for public reforms, and a desire to give "power" to the people. Together, he was seeking change - or what he called tabdeli. Thousands had gathered at the PTI's Lahore gathering in 2011, making Khan a formidable contender by the 2013 general elections.

The PR rebranding had paid: had transformed from a Western captain to an Islamized kaptan (Urdu word for captain). These mass gathering were called tsunamis - a symbol for the revolutionary change that Imran Khan would bring; using his "bat" he would "knock out" the wicked and corrupt and lead the country 
to the "people's victory" and "glory." This image was not accidental: it was crafted in the speeches Khan delivered. While using references to Islam and anti-corruption slogans, he was also able to masterfully use crude, common, and at times bold language to challenge the status quo, which resonated with the masses. He was considered bold for calling out the state's pattern of taking a "begging bowl" to the IMF or US. At the same time, he crudely yet hysterically poked fun at Zardari and the Sharifs on the basis of their appearances or policy decisions, evoking deep emotions through his charisma combined with a "common" style (Kari, 2019).

Khan became a pop cultural icon. Clothing lines designed women's clothing such as kurtas and scarfs with Khan's faces on them; kids and women painted their faces with the colour of PTI flags for the rallies (Dawn 2015). Fan carried or wore pop-art posters and badges. Wearing an Imran Khan themed item was a political statement against the status quo. Khan's online army of insafyans was busy sharing video featuring his rallies and quotes, as well as memes comparing him to the country's founding father, Muhammad Ali Jinnah (Mufti, 2016).

Polls showed that 68 percent saw Khan as the favoured leader in the county. During this period, Khan's "official account got around 100,000 hits daily and a Facebook account [received] 500,000 [hits]" (Mufti, 2016). The virtual space worked in his favour; given his background as a sports star, he knew how to optimize his public presence and earned the title "Facebook Khan" (Gulzar, 2018). Khan was a national populist phenomenon who captivated conventional and social media.

Social media followers still rave when Khan's official account posts his workout pictures, which make him seem active, hard-working, and glamorous compared to his counterpart Nawaz Sharif, known for his gluttonous indulgences. Khan's social media army is highly intolerant of any opposition directed at their leader; they have been known to be abusive towards various factions of society, a sign of how deeply they believe in Khan and his message. Some call them "blind followers"
(Mehdi, 2013). The supporters' sentiments have been adopted by Khan's increasingly autocratic populism. He has openly targeted his critics by calling them agents of "India's fascist government"; since taking power, he has simply used regulatory authorities to muffle dissent or criticism directed towards him or the party.

\section{From Pakistan's Last Hope to "U-Turn" Khan}

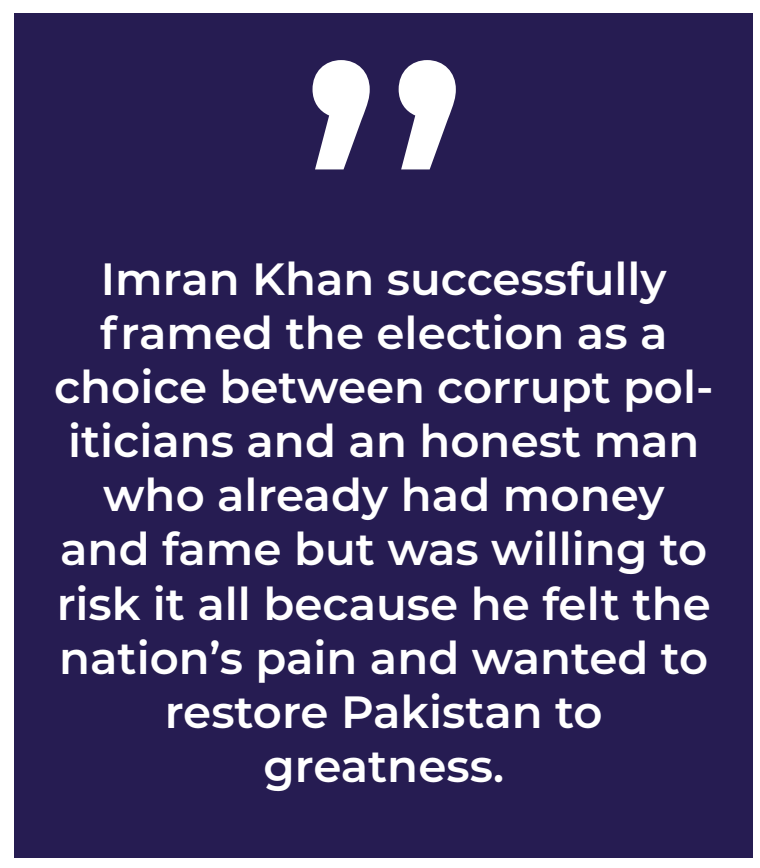




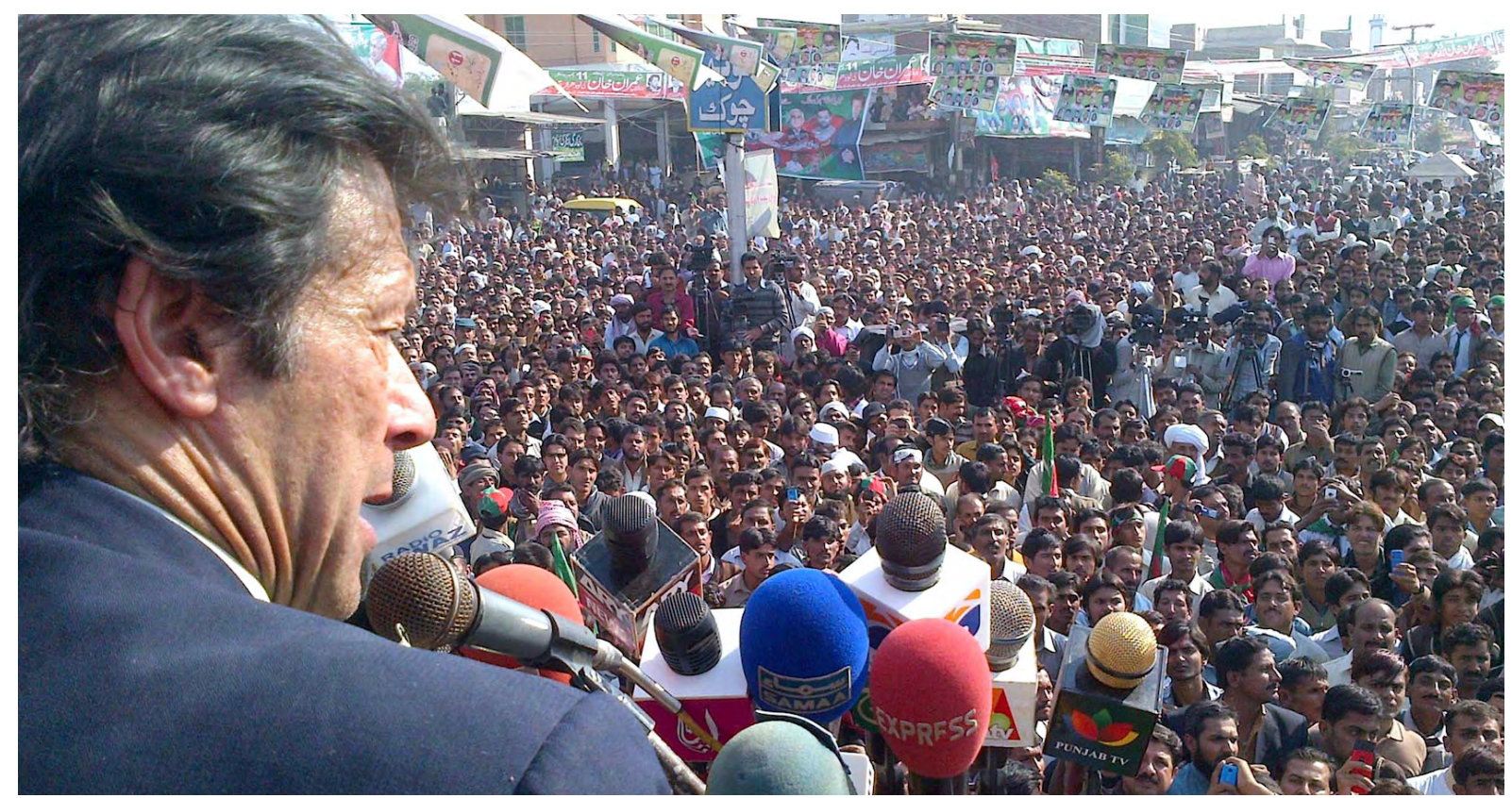

Tehreek-e-Insaf (PTI) Chairman, Imran Khan addresses to his supporters during public gathering held on December 11, 2012 in Lodheran. Photo: Asianet-Pakistan

\section{Mainstream Opposi- tion (2013-2018)}

Before 2013, Khan announced that his party would hold internal by-elections to prove they were different from the mainstream parties, which remain feudalistic and hereditary. This further strengthened his image as a populist outsider who was willing to diverge from business as usual. However, this was merely a distraction from the criticism that was mounting when PTI welcomed "electable" politicians - defectors from the mainstream political parties (Mufti, 2016).Khan's experience made him understand the need for electable politicians. Khan argued: "You contest elections to win. You don't contest elections to be a good boy. I want to win. I am fighting elections in Pakistan, not Europe. I can't import European politicians" (Rehman 2018). In a party statement, PTI said: "The nation must strengthen the hands of Imran Khan since he is the only politician who can steer the country out of the prevailing crisis" (Sadaqat, 2017). Thus, anyone critical of the party's leader was a supporter of the corrupt elites - or, worse, an unpatriotic citizen who did not want to make Pakistan a better place. "True people" were those who supported PTI; the rest were naive or traitors and following the "old ways"; they weren't ready for the change that would build a "New Pakistan."

Two major developments occurred when Imran Khan secured his tenure in the 2013 elections. Firstly, PTI formed a provincial government in KPK province by aligning with the ultra-right Jamaat-e-Islmai (JI). Khan pledged to reform KPK over the next five years. The party implemented new policies, include welfare reforms, a reformist agenda for public office, an effort to improve technology, and calls for justice. All of this was in line with Khan's promises for a naya ${ }^{[17]}$ Pakistan (Daudzai, 2018).

The technocratic solutions in KPK, made to directly benefit the people, were placed in sharp contrast to the infrastructure-led developments made in Punjab, the stronghold of the Sharif brothers and the ruling party. He mocked the PML-N leaders as jangla-Sharifs with their jangla bus project:; ${ }^{[12]}$ While Khan's policies benefitted the people, the PML-N was accused of using development projects to support their steel business by pocketing public funds (Daily Motion, 2017). PTI's tree planting drive in KPK also earned Khan great support, as he became a rare politician who was concerned about climate change in a country where the leaders never pay attention to it (Gishkori, 2020). 
Unfortunately for Khan and the PTI, it was soon clear that his populist agenda was not easily translatable into effective policies. While KPK was the model for PTI's policies, the technocratic reforms brought little development for the common people, as governance - especially at the local level - remained incapacitated, making it impossible to implement policies (Daudzai, 2018).

Moreover, Khan had pressed for "peaceful" resolutions to the insurgent violence in the province; yet during the PTI's tenure, two military operations were carried out - Operation Zarb-e-Azb and Operation Radd-ul-Fasaad. Further, to appease the JI faction of their coalition, Khan turned a blind eye to the Islamization of school curriculums in the province; rather than rehabilitation and deradicalization - a PTI promise - public education was Islamized, with Quran classes made compulsory in schools (Abbasi, 2017; Dawn, 2014).

Ironically, Khan - who had opposed the Lahore transit project launched by Shahbaz Sharif - developed his very own metrobus project in Peshawar, KPK's capital. He carefully marketed it as holistic, transparent, cost effective, and for the people; in reality, the project was behind schedule and over budget (Khan, 2019). And after having railed against corruption, Khan's "tree tsunami" project was embroiled in a corruption scandal (Gishkori, 2020).

To divert attention from PTI's failure to deliver on its promises, Khan used his time in office to attack PML-N's leadership. It was an effort to gain anti-establishment support. Khan's magnetic presence in the media allowed him to shift attention elsewhere. His crafty oratory, frank mannerisms, and fiery speeches made him the man to "save" Pakistan from the PML-N's corrupt leadership.

Khan successfully framed the election as a choice between corrupt politicians and an honest man who already had money and fame but was willing to risk it all because he felt the nation's pain and wanted to restore Pakistan to greatness (Yousaf, 2015; Dailymotion, 2016).

His skills were highlighted when the
2014 "Azadi March" was launched. It featured scores of political rallies across the country, and PTI joined hands with the right-wing religious party, Pakistan Awami Tehreek (PAT), which was spearheaded by Dr. Tahir-ul-Qadri for a mass sit-in in Islamabad. The mission of the march was to "unmask corruption," but Khan famously said, "This [the Azadi March] is beyond it [election rigging campaign]... the Pakistani people are not sheep that can be herded; we must empower people" (Dailymotion, 2014).

The usual jalsas were attended by thousands. They were no longer just for the middle class, but the working class, too. Khan gained support for his naya Pakistan agenda. His plan merged three key elements: Islamism, conspiracies, and a promise for welfare reforms. The country was seeing price hikes of basic commodities despite huge foreign investments being made by China. Khan merged the ideologies of welfare-ism and Islamism when he promised that naya Pakistan would be modelled on the state of Medina, from the times of Prophet Mohammad. Khan promised to end corruption in 19 days and terrorism in 90 days, and a key feature of this promise hinged on bringing "back every single penny of the looted money from the corrupt political leaders" (The News, 2020).

Khan introduced a highly ambitious 100day agenda which promised to bring back looted wealth and to implement welfare policies and governance for the people (Pakistan Today, 2018). His party has presented him as the "struggling hero" who sleeps on the ground or in a container, in the cold, just like the ordinary people. The party has also emphasized his struggle to bring power to the Pakistani people and to guide them in the light of the Qur'an and best Islamic practices, to eliminate the injustices and corruption of the political elite and foreign powers (Dailymotion, 2014).

The release of the Panama Papers further aided Khan's cause of driving out "corrupt politicians," when the names of Nawaz Sharif and his family members surfaced in money embezzlement cases. Khan promised vengeance and liberation from the "blood sucking" politicians, a 
message that especially resonated with young voters. One of his speeches summarized his tone: "Nawaz Sharif! Nawaz Sharif you shall be held accountable! You all shall be held accountable! Nawaz Sharif you will be the first one held accountable and after that each and every one shall be accounted for!" (YouTube, 2016). The crowd chanted, "Go Nawaz Go," in support of Khan - the chant became the number one trending hashtag in Pakistan.

In addition to the mass rallies, Khan pushed court cases against Nawaz Sharif and his family members; this led to the former being disqualified from office. During a "Thanksgiving" jalsa ${ }^{[13]}$ Khan started his speech by thanking Allah and congratulating the masses on their first "victory." He claimed this was only the beginning of the country's journey to greatness (Khan, 2016). Like most populists, Khan promised deliverance without clear plans, yet the pro-public sentiment of his statements earned considerable support among the disaffected populace.

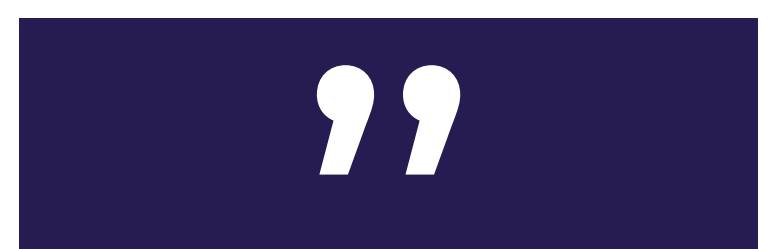

Imran Khan previously criticized politicians as "ribbon cutters" who used ceremonies for PR purposes; however, since assuming office, he has attended countless ceremonies of projects that have been launched at the planning level but have not yet been fulfilled. Faced with constant U-turns, Khan has also used a blend of conspiracy theories and misuse of state institutions to distract from the shortcomings of his leadership and government.
By 2018, Khan had transformed into a kaptan by promising a Muslim welfare state where all the corrupt sinners would be jailed and Pakistan would no longer be a beggar or a puppet of America. Nawaz Sharif's disqualification was his trophy, which he flaunted to the public ahead of the 2018 elections.

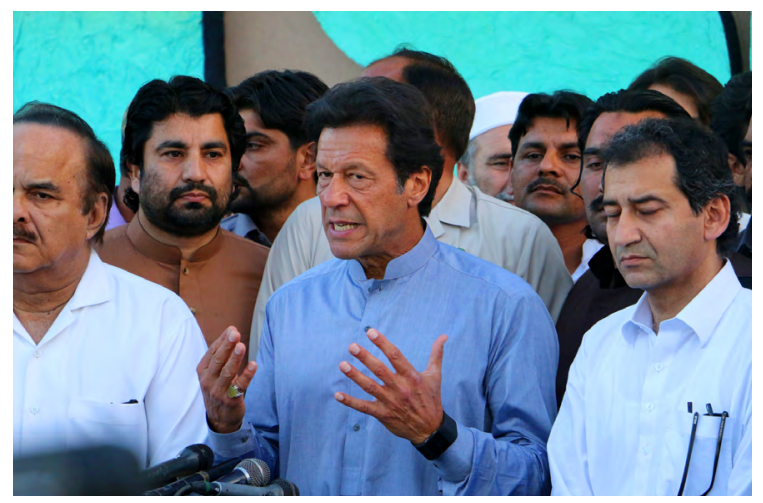

Imran Khan, addresses a press briefing on April 20, 2016 in Islamabad. Photo: Jahanzaib Naiyyer

\section{Leadership (2018-Present)}

Since assuming office as prime minister, Khan has done something of a U-turn. Since coming to power, the PTI has been unable to deliver on any of its promises, other than building a special task force to recover looted national wealth (Dawn, 2021). Promises of shelter, social welfare, youth job creation, access to quality education, and other ideals have been left on the drawing board or halted (Dawn, 2021). For instance, the promise to end corruption in the first 100 days vanished.

Imran Khan previously criticized politicians as "ribbon cutters" who used ceremonies for PR purposes; however, since assuming office, he has attended countless ceremonies of projects that have been launched at the planning level but have not yet been fulfilled (Qayum, 2020).

To gain clout, Khan has successfully renamed welfare programs for PR purposes; for example, the Benazir Income Support Program's (BISP) elements have been merged and branded with the Ehsas Welfare Program; and health cards that were launched during the last government are 
now rebranded as the Sehat Suhalat Program (Shat Suhalat, 2021; Junaidi, 2016). Such rebranding is a common practice in Pakistan. Khan promised to end Pakistan's "brain drain" by inviting technocrats from overseas to "fix" the country, and so far, it has ended in a disaster, as Tania Aidrus, who was leading the digital Pakistan initiative, has resigned, and Zafar Mirza, the advisor on heath, did the same. Khan's failure to deliver has meant that his promise to attract foreign investment from expat Pakistanis has failed to materialize (Khan, 2020).

Not only has Imran Khan been unable to instil change, but under his leadership, a lot of backtracking from promises has been made. Two examples include Dr. Atif Mian being dismissed from the Economic Advisory Council (EAC) based on his religious identification with the Ahmadi school of thought, ${ }^{[14]}$ and Khan taking "the begging bowl" to the International Monetary Fund (IMF) after years of severe criticism of the IMF (Farmer, 2020; Dawn, 2020).

Faced with constant U-turns, Khan has used a blend of conspiracy theories and misuse of state institutions to distract from the shortcomings of his leadership and government. Since coming into government, he has used the Pakistan Electronic Media Regulatory Authority (PEMRA) to attack opposition media such as the Jang Group and subsidiaries such as Geo Channel (Ellis-Petersen \& Baloch, 2019). Under the Khan government, any anti-state or government content seen on social media is portrayed as an "outside" attack, intended to alter the perspectives of Pakistani citizens (Butt, 2021).

Moreover, the National Accountability Bureau (NAB) has, throughout PTI's tenure, targeted various PML-N leaders on suspicion and accusations of corruption. While there are credible accusations of corruption, PTI has mostly escaped scrutiny despite similar allegations (Farooq, 2020; Shar; 2019, Zubair, 2019). In addition to PEMRA, Khan's government has created tighter rules for social media regulation under the Citizens Protection (Against Online Harm) Rules, 2020; these acts grant the government a permit to ask Google, YouTube, and other sites to ban or block content they consider unfit (Chabba, 2020).

Khan has also been directly confrontational towards the judiciary. In 2007, he went on a hunger strike to support the judiciary, and in 2017, he praised them for their "just" decision to dismiss Nawaz Sharif from office; during his tenure, he has pressured the judiciary on two occasions. Khan and the PTI used parliament to overrule the judiciary, extending the service tenure of the Chief of Army Staff. $\mathrm{He}$ also challenged the death sentence handed out to dictator Pervez Musharraf. Referencing Musharraf's death sentence, Khan said, "People's trust in judicial system has been shaken" (Dawn, 2020).

Khan's tenure has seen increasing inflation and unemployment, in addition to the already dire economic conditions. The opposition parties have formed a coalition to challenge his office. Khan has called this opposition anti-state and enemies of the state; he's called them "Indian" agents and members of foreign plots against Pakistan. This populist rhetoric resonates with Pakistanis who have been using conspiracy theories for decades to externalize the nation's failures. Thus, it has now become a fight between the "state" and its "people." Imran Khan has publicly called Nawaz Sharif a traitor, and Khan's government has banned media from airing Sharif's speeches due to "seditious" content (Dawn, 2020).

Khan and PTI have also deflected attention by externalizing blame. He uses the "honest man" strategy, positioning himself as the one humble man the people can trust. He believes that he had an "unfair" start because the system is so corrupt and damaged that he cannot deliver his promises with 100 days. He admits his failures and has pled with the people to give him time; he promises he will deliver only if they have "faith in him" (Khawar, 2020). Simultaneously, he has also externalized blamed, pointing the finger at India for allegedly sponsoring terrorism in the country and lobbying against Pakistan in the global arena. These are highly sensitive nerve endings amongst the public, who feel touched by Khan's humbleness while also feeling sorry for his plight. All the while, they believe his claims; a majority of 

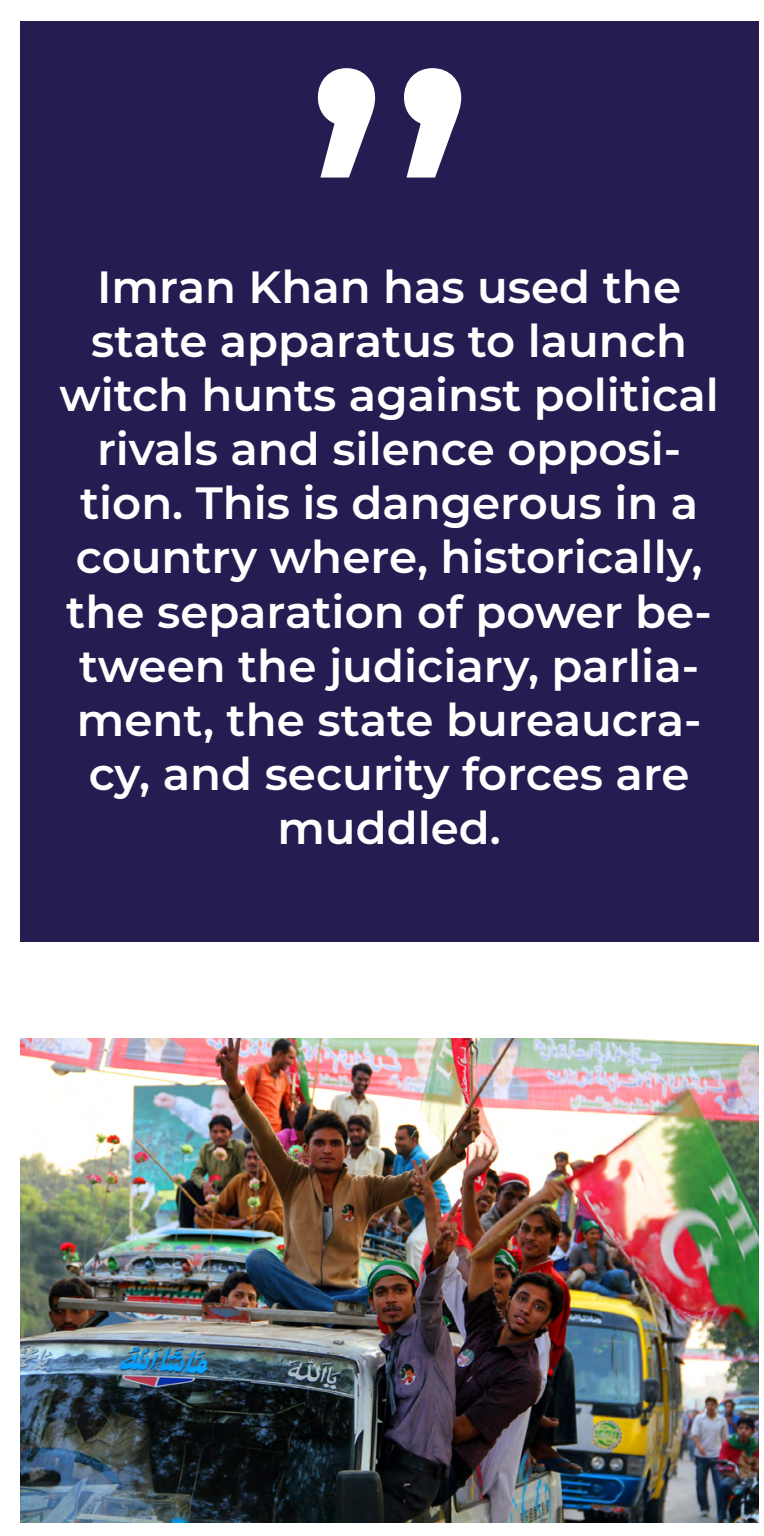

Enthusiastic Youth going towards the venue Minar-e-Pakistan to attend Imran Khan's political rally on October 30, 2011 in Lahore, Pakistan. Photo: Jahanzaib Naiyyer

\section{Khan's Populism and its Consequences}

Imran Khan is not the first to use populism to wield power in Pakistan. Religious leaders, political figures, and military generals have used faith and the promise of a better life to gain support or legitimize their actions. The uniqueness of Khan's populism lies in the fact that he has been able to condense a host of diverse ideologies into a coherent populist narrative
An example of this is the Single National Curriculum Plan (SNCP), which aims to bring equity to the education system by having a single curriculum for public and private schools. In a country where quality education is a privilege few enjoy, SNCP is a symbol of equity and the promise of justice in naya Pakistan. At the same time, its highly Islamized aspects - including teaching Quranic verses and the life and sayings of the Prophet (from a Sunni interpretation) - appease the religious sentiments of the populace. SNCP also represents a move away from "Westernized" education to a more indigenous model. PTI advertises SNCP as true to the values and norms of Pakistani culture (in reality, Sunni Islamic culture). Thus, in one policy proposal, Khan combines anti-Western and anti-elitism with Islamism and reform.

In three years, Khan has used the state apparatus to launch witch hunts against political rivals and silence opposition. This is dangerous in a country where, historically, the separation of power between the judiciary, parliament, the state bureaucracy, and security forces are muddled. Khan has again merged various ideologies such as anti-corruption, anti-elitism, conspiracies, and a quest to make Pakistan a "just Islamic state" modelled on Medina to justify his vindictive, autocratic behaviour.

These choices have set up a choice between the "people" - that is, those pure ones on the right (religious) side - and those who oppose the people. This latter group includes traitors and Indian spies, members of the elite, or those brainwashed by Western sex, drugs, and rock and roll. The "otherization" of critics and those who do not identify with Khan's narrative leaves little room for pluralism.

Khan's merged ideologies and populist rhetoric are primarily defined by Islamism as a way of viewing the world and an agent of change to answer all social issues. His supporters are overwhelmingly young (again, a majority of Pakistanis are under 30), which makes his support worrying. His tenure has promoted Quranic education, Muslim victimization, a wave of pan-Islamism, and fear of the "West" and non-Muslims. For these policies, and 
radicalizing the country's youth, Khan has been named amongst "The Muslim 500" (The News, 2020). When a number of Shia and ethnically Hazara were massacred in 2021, Khan blamed India for "sponsoring terrorism," even though his policies have done little to ensure that interfaith harmony is promoted in an already radicalized society.

Captaincy of the country has led Khan to make many compromises or U-turns; his image as a political "outsider" or miracle worker are no longer valid; he has struggled to turn populist dreams into the reality of a naya Pakistan. To cover his shortcomings, like other populist leaders, he has misused power and deflected blame to imagined external threats. He also doubled down on his populism, "otherized" internal critics, and tried to construct their criticism as illegitimate. Moreover, by codifying populism into educational policy and spreading conspiracy theories, Khan's tenure is likely to have far-reaching consequences for Pakistan's social fabric. 


\section{REFERENCES}

— (1997). "Khan willing to have paternity test in child case." Irish Times. Aug. 15, 1997. https:/l www.irishtimes.com/news/khan-willing-to-have-paternity-test-in-child-case-1.97027 (accessed on January 1, 2021).

- (2005). "When you speak out, people react." The Guardian. Aug. 31, 2005. https://www. theguardian.com/sport/2005/aug/31/cricket.pakistan (accessed on January 1, 2021).

- (2011). "Imran Khan to protest against drone strikes." Express Tribune. April 7, 2011. https:// tribune.com.pk/story/144916/imran-khan-to-protest-against-drone-strikes (accessed on January 1, 2021).

- (2012). "Khan, Taliban and the Crackpot Science." Dawn. Nov. 2, 2012. https://www.dawn. com/news/760981/khan-taliban-and-the-crackpot-science (accessed on January 1, 2021).

- (2014). "Wazirabad scuffle." Dawn. Oct. 3, 2014. https://www.dawn.com/news/1135800/ (accessed on December 27, 2020).

- (2015). "Siyasat and style: The story behind Imran's kurta and Altaf Bhai's aviators." Dawn. May 29, 2015. https://www.dawn.com/news/1181520 (accessed on January 1, 2021).

- (2018). "Nominated Punjab CM paid blood money to resolve murder case." In the News. Aug. 19, 2018. https://dunyanews.tv/en/Pakistan/453202-Nominated-Punjab-CM-UsmanBuzdar-blood-money-murder-case-PTI (accessed on December 30, 2020).

- (2018). "16 promises PTI govt has broken in first month in office." Pakistan Today. Sep. 20, 2018. https://www.pakistantoday.com.pk/2018/09/20/16-broken-promises-of-pti-govt/ (accessed on December 27, 2020).

- (2019). "Joining US War on Terror After 9/11 "One of Biggest Blunders": Imran Khan." NDTV: Press Trust of India. Sep. 24, 2019. https://www.ndtv.com/world-news/imran-khansays-joining-us-war-on-terror-after-9-11-attack-was-biggest-blunder-2105964 (accessed on January 1, 2021).

- (2020). "PPP, PML-N politics over." The News. May 11, 2020. https://www.thenews.com.pk/ print/657023-ppp-pml-n-politics-over (accessed on January 1, 2021).

- (2020). "The dark side of Imran Khan: When he 'sparked' riots in 2005." The Week. Jan 2, 2020. https://www.theweek.in/news/world/2020/06/26/the-dark-side-of-imran-khan-whenhe-sparked-riots-in-2005.html (accessed on January 4, 2021).

- (2020). "People's trust in judicial system has been shaken: Imran." Dawn. May 30, 2020. https://www.dawn.com/news/1560336 (accessed on January 4, 2021).

- (2020). "Imran Khan declared Man of the Year by 'The Muslim 500'." The News. Aug. 23, 2020. https://www.thenews.com.pk/print/704715-imran-khan-declared-man-of-the-yearby-the-muslim-500 (accessed on January 4, 2021).

- (2020). "Under pressure govt backtracks on Atif Mian's appointment; removes economist from advisory council." Dawn. Oct. 22, 2020. https://www.dawn.com/news/1431495/under-pressure-govt-backtracks-on-atif-mians-appointment-removes-economist-from-advisory-council (accessed on December 28, 2020).

- (2020). "India helping Nawaz in 'attempts to weaken army', says PM Imran." Dawn. Oct 2, 2020. https://www.dawn.com/news/1582671 (accessed on December 28, 2020). 
- (2021). "Naya Pakistan Tracker." Dawn. Jan. 4, 2021. https://www.dawn.com/nayapakistan/ (accessed on January 4, 2021).

- (2014). "Imran Khan Speech 26 Aug - Azadi March." Daily Motion. https://www.dailymotion.com/video/x24mg2g (accessed on January 1, 2020).

— (2016). "Imran Khan criticises PM after Panama leaks." YouTube. https://www.youtube. com/watch?v=uDmltsov_Ug (accessed on December 27, 2020).

- (2016). "Imran Khan Blasting Speech in PTI 'Thanksgiving' Rally." Daily Motion. https:// www.dailymotion.com/video/x50c8uh (accessed on December 27, 2020).

— (2017). "Metro bus critic Imran Khan answers on building similar Peshawar project." Daily Motion. https://www.dailymotion.com/video/x6b48au (accessed on January 1, 2020).

Aafreedi, J. Navras. (2019). "Antisemitism in the Muslim Intellectual Discourse in South Asia." Religions. 10, 442. doi:10.3390/rel10070442 (accessed on January 1, 2021).

Abbasi, Ansar. (2017). "KP govt makes Quranic education compulsory in schools." The News. Jan. 21, 2017. https://www.thenews.com.pk/print/180736-KP-govt-makes-Quranic-education-compulsory-in-schools (accessed on December 27, 2020).

Afzal, Madiha. (2019). "Imran Khan's incomplete narrative on the Taliban." Brookings. Oct. 13, 2019. https://www.brookings.edu/blog/order-from-chaos/2019/10/14/imran-khans-incomplete-taliban-narrative/ (accessed on December 27, 2020).

Boone, Jon. (2012). "This article is more than 8 years old Imran Khan says Taliban's "holy war' in Afghanistan is justified by Islamic law." The Guardian. Oct 14, 2012. https://www. theguardian.com/world/2012/oct/14/imran-khan-taliban-afghanistan-islam (accessed on January 1, 2021).

Butt, I. Ahsan. (2021). "Has a 'fifth generation war' started between India and Pakistan?" Aljazeera. Jan. 4, 2021. https://www.aljazeera.com/opinions/2021/1/4/are-india-and-pakistanin-a-fifth-generation-war (accessed on 4 January 2021).

Chabba, Seerat. (2020). "Pakistan's new internet laws tighten control over social media." DW. Feb. 28, 2020, https://www.dw.com/en/pakistans-new-internet-laws-tighten-control-over-social-media/a-52375508 (accessed on January 1, 2021).

Chowdhry, Aisha and Houreld, Katharine. (2012). "Pakistan halts drone protest led by ex-cricketer Imran Khan." Retuters. Oct. 7, 2012. https://www.reuters.com/article/us-pakistan-drone-protests/pakistan-halts-drone-protest-led-by-ex-cricketer-imran-khan-idUSBRE89609Q20121007 (accessed on January 1, 2021).

Ellis-Petersen, Hannah and Shah Meer Baloch. 2019. "Extreme fear and self-censorship: media freedom under threat in Pakistan." The Guardian. Nov. 5, 2019. www.theguardian. com/world/2019/nov/05/extreme-fear-and-self-censorship-media-in-pakistan-under-attack (accessed on December 28, 2020).

Farmer, Ben. (2019). “Imran Khan's Pakistan forced to swallow IMF medicine in return for \$6bn bailout." Telegraph. May 13, 2019. www.telegraph.co.uk/business/2019/05/13/imrankhans-pakistan-forced-swallow-imf-medicine-return-6bn/ (accessed on December 28, 2020).

Farooq, Umar. (2020). "Jahangir Tareen returns to Pakistan from UK." Dawn. Nov. 6, 2020. Jahangir Tareen returns to Pakistan from UK (accessed on January 1, 2021). 
Gishkori, Zahid. (2020). "Billion Tree Tsunami Project faces over Rs410m loss." The Nation. Nov. 9, 2020. https://www.thenews.com.pk/print/726501-billion-tree-tsunami-project-facesover-rs410m-loss (accessed on January 1, 2021).

Innskeep, Steven. (2008). "Imran Khan Brings Anti-Musharraf Effort to US." NPR. January 25, 2008. https://www.npr.org/templates/story/story.php?storyld=18402782 (accessed on December 28, 2020).

Junaidi, Ikran. (2016). "PM launches health scheme for the poor." Dawn. Jan. 1, 2016. https:// www.dawn.com/news/1229970 (accessed on December 28, 2020).

Kari, Maria. (2019). "At Imran's US Jalsa, only the containers were missing." Images: Dawn. Dec. 3, 2019. https://www.dawn.com/news/1495735 (accessed on January 1, 2021).

Khan, Ismail. (2019). "Damning report of public money waste on Peshawar BRT." Dawn. https://www.dawn.com/news/1473563 (accessed on January 1, 2021).

Khan, Sanaullah. (2020). "Tania Aidrus, Dr Zafar Mirza resign as special assistants to PM over 'criticism'." Dawn. July 30, 2020. https://www.dawn.com/news/1571794 (accessed on January 1, 2021).

Khawar, Hassan. (2020). "Is the PM allowed to err?" The Express Tribune. Dec. 29, 2020. https://tribune.com.pk/story/2277770/is-the-pm-allowed-to-err (accessed on December 30, 2020).

Mehdi, Tahir. (2013). "Four reasons why PTI could not change our political culture." Dawn. July 23, 2013. https://www.dawn.com/news/1031329 (accessed on December 28, 2020).

Mir, Hamid. (2018). "The Imran Khan I know." The News. Aug. 7, 2018. https://www.thenews. com.pk/print/351820-the-imran-khan-i-know (accessed on December 28, 2020).

Mufti, Mariam. (2016). "Pakistan Tehrik-e-Insaaf: New Phenomenon or Continuation of the Political Status Quo?" NORIA. Oct. 22, 2016. https://www.noria-research.com/south-asia-5pakistan-tehrik-e-insaaf/ (accessed on January 1, 2021).

Mullah, Ayesha, (2017). "Broadcasting the Dharna: Mediating "Contained" Populism in Contemporary Pakistan." International Journal of Communication, 11, 4181-4196. 19328036/20170005 (accessed on December 28, 2020).

Qayum, Khalid. (2020). "Undue delays plague Imran's Naya Pakistan Housing Scheme in Punjab." The Express Tribune. April 28, 2020. https://tribune.com.pk/story/2208498/unduedelays-plague-imrans-naya-pakistan-housing-scheme-punjab (accessed on December 28, 2020).

Rajghatta, Chidanand. (2005). "Holy mess: US mag blames Imran." The Times of India. May 16, 2005. https://timesofindia.indiatimes.com/world/us/Holy-mess-US-mag-blames-Imran/ articleshow/1111381.cms (accessed on December 27, 2020).

Rehman, Atika. (2018). "You can't win without electables and money: Imran." Dawn. July 5, 2018. www.dawn.com/news/1418060 (accessed on December 27, 2020).

Sadaqat, Muhammad. (2017). "PTI leader admits 'failures' in K-P." Express Tribune. March 13, 2017. https://tribune.com.pk/story/1353647/time-needed-pti-leader-admits-failures-k-p (accessed on December 27, 2020).

Sehat Sahulat Program (2021). https://www.pmhealthprogram.gov.pk/ (accessed on January 4,2021$)$. 
Shar. (2019). "50 shades of politics: In the end, PTI will be a graveyard of resigned politicians." The Express Tribune.Feb. 08, 2019. https://tribune.com.pk/article/78471/50-shades-ofpolitics-in-the-end-pti-will-be-a-graveyard-of-resigned-politicians (accessed on December 27, 2020).

Walsh, Declan. (2007). "Court dismisses challenges to Musharraf." The Guardian. Nov. 20, 2007. https://www.theguardian.com/world/2007/nov/20/pakistan.international (accessed on December 27, 2020).

Yousaf, Salman. (2015). "Political marketing in Pakistan: exaggerated promises, delusive claims, marketable development projects and change advocacy: An evidence from May 2013 general elections." Journal of Public Affairs. 16(2). DOI: 10.1002/pa.1562 (accessed on January 1, 2021). 


\section{FOOTNOTES}

[1] Tabdeli is an Urdu work that is used to describe reform and change. This word has become synonymous with Imran Khan.

[2] The Indus River is the largest river system in Pakistan. Historically, cities and settlements, from north to south, have developed along the river. Thus, it holds immense cultural significance.

[3] Pakistan Movement for Justice

[4] In Pakistan possessing and drinking alcohol is a punishable offense.

[5] In Pakistan sex outside marriage is a punishable offence. The Hudood Ordinances, at the time, consisted of Zina (extramarital) Ordinance, which before 2006, could hand jail sentences of up to 10 years along with stoning to death for the adulterer and a public whipping of 100 lashes for a fornicator.

[6] In Pakistan 'missing persons' are people who have gone missing by being abducted or killed by state intuitions. These occurrences have also been called the 'enforced disappearances.'

\section{[7] Captain}

[8] Talking about the central PPP Government and PML-N Punjab government

[9] Funfairs where locals celebrate with family and friends. They were once a common occurrence in Pakistan, but the wave of suicide bombings severely limited or hampered these once frequent occurrences where dance and music were common.

[10] It is noteworthy that Pakistan has one of the youngest populations around the world. People under the age of 30 make up over $64 \%$ of the total population.

[11] New Pakistan

[12] Jangla-Sharif refers to the Metro Bus project in Lahore. PML-N had heavily invested in infrastructure projects during their two terms in Punjab.

[13] After the disqualification of Nawaz Sharif Khan gathered his supports in a 'Thanksgiving' rally as they were ridded off 'kind of corrupt.'

[14] Ahmadis are a subsect of Muslims who have been declared non-Muslims in Pakistan; they are a highly persecuted group who face discrimination and even loss of life due to their religious affiliation. Extremist right-wing groups consider them wajib-ul-qatal (eligible to kill). 


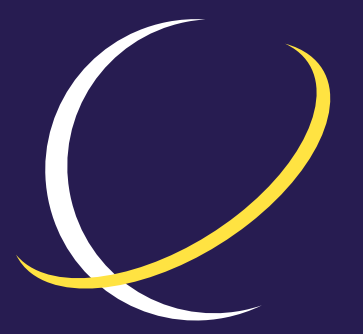

\section{ECPS \\ EUROPEAN CENTER for POPULISM STUDIES}

\section{ABOUT ECPS}

The European Center for Populism Studies (ECPS) is an independent, nonpartisan, nonprofit organization, based in Brussels, for research on and analysis of challenges posed by the resurgence of political populism. ECPS facilitates collaboration among networks of academic experts, practitioners, policymakers, media, and other stakeholders. ECPS offers a platform for the exchange of policy solutions on issues relating to rising populism and provides insights for policy-making and critical analysis to raise broader awareness and engagement through:

\section{Publications}

\section{Academic publications}

Policy reports

White papers

Commentaries

Podcasts and interviews with experts

Events, seminars, workshops, and conferences

\section{Research Programs}

Authoritarianism

Digital Populism

Economics

Environment \& Climate

Extremism \& Radicalisation

\section{Gender}

Human Rights

Foreign Policy

Leadership \& Persona

Migration

\section{ECPS Youth Program}

ECPS Academy 